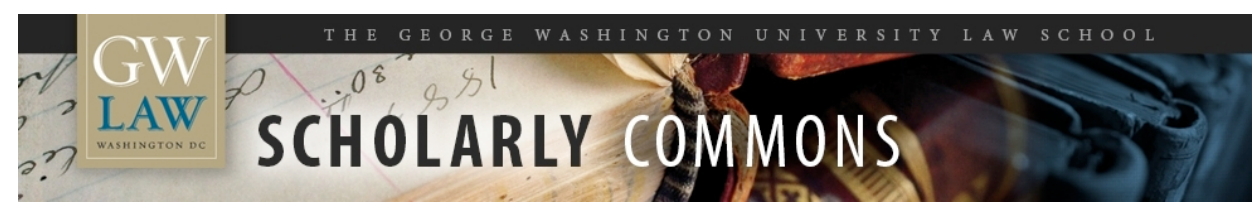

GW Law Faculty Publications \& Other Works

Faculty Scholarship

2009

\title{
Making Sense of Procedural Injury
}

Richard J. Pierce Jr

George Washington University Law School, rpierce@law.gwu.edu

Follow this and additional works at: https://scholarship.law.gwu.edu/faculty_publications

Part of the Law Commons

\section{Recommended Citation}

Pierce, Richard J. Jr, "Making Sense of Procedural Injury" (2009). GW Law Faculty Publications \& Other Works. 865.

https://scholarship.law.gwu.edu/faculty_publications/865

This Article is brought to you for free and open access by the Faculty Scholarship at Scholarly Commons. It has been accepted for inclusion in GW Law Faculty Publications \& Other Works by an authorized administrator of Scholarly Commons. For more information, please contact spagel@law.gwu.edu. 


\title{
Making Sense of Procedural Injury
}

\author{
Richard J. Pierce, Jr.
}

\section{Procedural injuries are "special" for standing purposes}

My goal in this essay is to try to make sense of the concept of procedural injury as courts use that concept to determine whether a petitioner has standing to obtain judicial review of an agency action. In 1970, the Supreme Court held that a court has jurisdiction to review an agency action only at the behest of a party who has suffered an injury that was caused by the agency action and that is redressable by a court. ${ }^{1}$ In subsequent cases, the Court applied a variety of tests to determine whether a challenged action "caused" a petitioner's injury. With rare exceptions, the tests varied between a requirement that the petitioner demonstrate a probable causal relationship between the challenged action and the injury and a requirement that the petitioner demonstrate a near certain causal relationship between the challenged action and the injury. ${ }^{2}$

In a footnote in its 1992 opinion in Lujan v. Defenders of Wildlife, however, the Court singled out procedural injuries for special treatment:

There is this much truth to the assertion that "procedural rights" are special: The person who has been accorded a procedural right to protect his concrete interests can assert that right without meeting all the normal standards for redressability and immediacy. Thus, under our case law, one living adjacent to the site for proposed construction of a federally licensed dam has standing to challenge the licensing agency's failure to prepare an

\footnotetext{
${ }^{*}$ Lyle T. Alverson Professor of Law, George Washington University. I am indebted to Jonathon Siegel and Roger Trangsrud for helping me find a point of entry into this project.

${ }^{1}$ Association of Data Processing Service Organizations v. Camp, 397 U.S. 150, 152-54 (1970).

${ }^{2}$ For detailed discussion of the cases, see Richard J. Pierce, Jr., Administrative Law Treatise $\S 16.5\left(5^{\text {th }}\right.$ ed. 2009).
} 
environmental impact statement, even though he cannot establish with any certainty that the statement will cause the license to be withheld or altered, and even though the dam will not be completed for many years. ${ }^{3}$

In a sense, the Court's acknowledgment that procedural injuries are "special" for standing purposes was no more than belated recognition of a reality that should have been obvious to any student of administrative law. In thousands of cases, courts have routinely decided whether an agency erred by refusing to grant a petitioner a statutorily or constitutionally required procedure, e.g., a hearing, without requiring the petitioner to demonstrate that the agency certainly, or even probably, would have reached a different result if it had granted the petitioner's request for a hearing. Courts have long been willing to address that procedural issue without any mention of standing based only on a petitioner's claim that it raised a material issue of contested fact that might plausibly be resolved differently after a hearing. Yet, since the Court had not previously addressed the issue of standing to redress a procedural injury, the 1992 footnote induced many circuit courts to address for the first time the question of when an alleged procedural injury suffered by a petitioner qualifies the petitioner for standing. ${ }^{4}$

The circuit court opinions fall in two categories with respect to the nature of the causal relationship they require between the omitted procedure and a

\footnotetext{
${ }^{3}$ Lujan v. Defenders of Wildlife, 504 U.S. 555, 572 n.7 (1992).

${ }^{4}$ Many of the procedural injury cases are resolved by deciding whether the procedure the agency failed to provide affected what the Court refers to as a "separate concrete interest" of the petitioner,.e.g., the agency action would damage a tract of land the petitioner uses for recreational purposes. I have discussed that class of disputes in detail elsewhere. See e.g., Richard Pierce, Issues Raised by Friends of the Earth v. Laidlaw Environmental Services: Access to the Courts for Environmental Plaintiffs, 11 Duke Environmental Law \& Policy Forum 207 (2001); Is Standing Law or Politics? 77 North Carolina Law Review 1741 (1999). For purposes of this essay, I am ignoring that important class of cases. I am focusing only on cases in which the agency's failure to provide the procedure at issue jeopardizes a separate concrete interest of the petitioner and in which the only question the court must resolve is whether the petitioner has demonstrated an adequate causal relationship between the omission of that procedure and the resolution of the underlying substantive dispute against the petitioner.
} 
substantive result that is unfavorable to the petitioner. In many cases, a petitioner prevails by alleging only that it was unlawfully deprived of a procedural right that might plausibly have changed the outcome of a substantive dispute. ${ }^{5}$ In other cases, however, a petitioner loses because a court concludes that it did not demonstrate that "it is substantially probable that the procedural breach will cause the essential injury to the plaintiff's own interest." ${ }^{\prime 6}$ The choice of the causal test to apply is outcome determinative. When a court applies the plausibility standard, it holds that the petitioner has standing because it is almost always plausible that provision of a procedural safeguard will change the outcome of a case. Conversely, when a court applies the probability standard, it holds that the petitioner lacks standing because it is usually impossible to prove that provision of a procedural safeguard will probably change the outcome.

\section{What can the harmless error doctrine tell us about the procedural injury doctrine?}

The Supreme Court has helped to provide a way of making sense of the procedural injury cases by issuing its 2009 opinion in Shinseki v. Sanders. ${ }^{7}$ In Shinseki, the Court addressed another long-neglected question - when is an agency's failure to provide a required procedure an error so harmless that a reviewing court should not use the omission as a basis to vacate and/or remand

\footnotetext{
${ }^{5}$ E.g., Electric Power Supply Ass'n v. FERC, 391 F. 3d 1255, 1261-62 (D.C. Cir. 2004); FEC v. NRA Political Victory Fund, 6 F.3d 821, 824 (D.C. Cir. 1993).

${ }^{6}$ E.g., Center for Law and Education v. Department of Education, 396 F. 3d 1152, 1159 (D.C. Cir. 2005); Florida Audubon Society v. Bentsen, 94 F. 3d 658, 664-64 (D.C. Cir. en banc 1996).

${ }^{7} 129$ S. Ct. 1696 (2009).
} 
the agency action. The procedural injury test and the harmless error test are doctrinally discrete. A court applies the procedural injury test at the beginning of the review process to determine whether an agency's omission of an arguably required procedure has caused an injury sufficient to confer jurisdiction on the court to review the challenged action. It applies the harmless error test at the end of the review process to determine whether an agency's omission of a required procedure constituted an error so unlikely to cause harm that the court would not be justified in vacating and/or remanding the challenged action.

Those differences in the timing, procedural posture, and effects of applications of the procedural injury and harmless error doctrines are important. They limit the value of any direct analogy between the two doctrines. I will return to a discussion of the implications of the differences between the doctrines after I extract as much value as I can from the similarities between the two.

The procedural injury doctrine and the harmless error doctrine are logically and functionally related. If a court concludes that a procedure is so important that its omission produced harm sufficient to justify a court in vacating and/or remanding the agency action, it seems logical that the court also should conclude that omission of the procedure caused the petitioner to suffer a procedural injury. The converse does not follow, however. A court cannot evaluate effectively many claims that a procedural error was harmless without reviewing the entire record of the proceeding. A court cannot engage in that review process unless it first determines that the petitioner suffered a procedural 
injury sufficient to allow the court to review the record of the agency action the petitioner is challenging.

In Shinseki, the Court held that section 706 of the Administrative Procedure Act $^{8}$ codifies the version of the harmless error rule that courts have long applied in civil cases. ${ }^{9}$ The Court then criticized and rejected the version of the harmless error rule that the Federal Circuit had been applying to decision making by the VA. The Court rejected the Federal Circuit's version for three reasons: (1) it relied on a series of "mandatory presumptions and rigid rules rather than case specific application of judgment, based upon examination of the record;" (2) it imposed an unreasonably high burden on the agency; and, (3) it imposed the burden of showing that an error was harmless on the agency rather than on the party that challenged the agency action. ${ }^{10}$

The Court then instructed lower courts to apply the harmless error rule to agencies the same way courts apply the rule to civil cases. The Court emphasized that the courts must apply the rule in a flexible manner, with the results dependent on the nature of the error and its likely effects on the outcome of the case:

$[T]$ he factors that inform a reviewing court's "harmless-error" determination are various, potentially involving, among other casespecific factors, an estimation of the likelihood that the result would have been different, an awareness of what body (jury, lower court, administrative agency) has the authority to reach that

\footnotetext{
${ }^{8} 5$ U.S.C. $\$ 706:$ " $[\mathrm{A}]$ court shall review the whole record . . . and due account shall be taken of the rule of prejudicial error."

${ }^{9} 129$ S. Ct. at 1704.

${ }^{10}$ Id. at 1705 .
} 
result, a consideration of the error's likely effects on the perceived fairness, integrity, or public reputation of judicial proceedings, and a hesitancy to generalize too broadly about particular kinds of errors when the specific factual circumstances in which the error arises may well make all the difference. ${ }^{11}$

The Court noted, however, that "courts may sometimes make empirically based generalizations about what kinds of errors are likely, as a factual matter, to prove harmful." 12

The Court's description of the application of the harmless error rule in the context of civil cases provides an accurate overview of the complex body of case law in which it has applied the harmless error rule. ${ }^{13}$ As the Court has recognized repeatedly, the harmless error rule is designed to allow courts to protect the fundamental procedural rights of parties in a manner that is consistent with avoidance of unnecessary costs in adjudicating cases. The leading treatise on civil procedure describes the rule in the following language:

At the heart of Rule 61 is the proposition that the critical consideration is the seriousness of the error not its occurrence. The difficulty is in gauging when an error is sufficiently serious that it

\footnotetext{
${ }^{11}$ Id. at $1704-06$.

${ }^{12}$ Id. at 1707.

${ }^{13}$ E.g., Neder v. United States, 527 U.S. 1 (1999); O’Neal v. McAninch, 513 U.S. 432 (1995); Kotteakos v. United States, 328 U.S. 750 (1946).
} 
has defeated "substantial justice" and affected "the substantial rights of the parties." ${ }^{\prime 14}$

The treatise emphasizes that the process of determining whether an error is harmless is "highly subjective" and it cautions against broad generalizations about application of the rule.

Consistent with the Court's opinion in Shinseki, however, the treatise then goes on to describe some of the empirically based generalizations that are reflected in the opinions in which courts apply the harmless error rule to procedural errors of various types. Thus, for instance, it describes errors in admitting or excluding evidence as "prime candidates" for application of the harmless error rule, ${ }^{15}$ while it describes the showing required to demonstrate that denial of a jury trial was harmless as "a very rigorous one." ${ }^{, 16}$ It describes errors in giving jury instructions as falling between errors in denying a jury trial and errors in making evidentiary rulings. ${ }^{17}$

It is easy to explain why courts apply the harmless error rule in quite different ways in these three classes of cases. The right to jury trial is so fundamental that courts rarely should forgive a judge's erroneous denial of that right by asking whether provision of a jury trial probably would have produced a different result in the case. If courts asked that question in every case in which a judge erroneously denied a request for a jury trial, the answer almost always

\footnotetext{
${ }^{14} 11$ Charles Wright, Arthur Miller \& Mary Kane, Federal Practice \& Procedure $\$ 2883$ (2d ed. 1995).

${ }^{15}$ Id. at $\$ 2885$.

${ }^{16}$ Id. at $\$ 2887$.

${ }^{17}$ Id. at $\$ 2886$.
} 
would be no. Empirical studies have consistently found that judges and juries would reach the same decision in the vast majority of cases. ${ }^{18}$ Thus, if courts applied a probability test to erroneous deprivations of the right to a jury trial, they would logically conclude that the error was harmless in most cases.

With the harmless error rule applied in that manner, trial judges would soon realize that they could erroneously deny motions for jury trials at little, if any, cost. That realization inevitably would cause them to tip the balance against grants of motions for jury trials in all close cases, thereby eroding de facto the right to jury trial. We place such a high value on the right to jury trial that we want judges to decide close cases by granting motions for jury trial. We obtain that result by making an erroneous decision denying a motion for jury trial costly, i.e., by applying to erroneous denials of jury trials a version of the harmless error rule that almost always yields a reversal that must then be followed by an expensive jury trial.

Erroneous evidentiary rulings raise quite different considerations. Given the complexity of the rules of evidence and the need for a judge to make a large number of evidentiary rulings in a typical trial, it is unrealistic to expect any judge to preside over a trial that is free of evidentiary errors. Even the best trial judges probably make at least a few erroneous evidentiary rulings in every trial. ${ }^{19}$ Yet, a

\footnotetext{
${ }^{18}$ E.g., Kevin Clermont \& Theodore Eisenberg, Trial by Jury or Judge: Transcending Empiricism, 77 Corn. L. Rev. 1124, 1126, 1137 (1992); Harry Kalven, The Dignity of the Civil Jury, 50 Va. L. Rev. 1055, 1063 68 (1964).

${ }^{19}$ One way of testing the accuracy of this assertion is to ask how often an evidence student submits an errorfree final exam paper. In my decades of teaching the subject to many hundreds of students, I have never seen a perfect paper. I must also admit that I always discover that the answer sheet I initially made up for grading purposes has errors that I correct as I read exam papers in which one or more students did a better job of answering a question than I did. Once I detect and correct the errors in my initial answer sheet, I regrade any of the exams that I previously graded using my initially flawed answer sheet.
} 
single erroneous ruling (or even a handful of erroneous rulings) is unlikely to change the outcome of a case. Moreover, we simply do not place as high a value on the right to a trial free of evidentiary errors as we do on the right to a jury trial. In this situation, it would be far too costly to require a retrial in every case in which a judge makes one or a few erroneous evidentiary rulings. We appropriately absorb that high cost only in the rare case in which a circuit court, after considering all of the evidence presented, concludes that the erroneous ruling probably affected the outcome of the case.

Errors in giving jury instructions are closer to errors in making evidentiary rulings than to errors in refusing to grant a motion for jury trial. Given the number of jury instructions and the difficulty of determining the precise language that should be included in each instruction, a trial that is free of all jury instruction errors is probably as rare as a trial that is free of all erroneous evidentiary rulings. Yet, it is more likely that an erroneous jury instruction on a critical issue will affect the outcome of a case than that an erroneous evidentiary ruling will be determinative of the outcome of the case. Moreover, it is easier for circuit courts to detect serious and material errors in giving jury instructions than it is for them to detect serious and material errors in making evidentiary rulings. Circuit court judges know far more about the abstract legal principles that trial courts should reflect in jury instructions than they do about the rules of evidence that trial judges must apply every day.

With two important exceptions, the application of the procedural injury doctrine should be informed by the same factors that explain the application of the 
harmless error rule. Both exceptions relate to the time and procedural posture of a case when a court applies each of the doctrines.

First, it is easy to apply a flexible, case specific version of the harmless error doctrine, but it is hard to apply a flexible case specific version of the procedural injury doctrine. By definition, a reviewing court has not yet looked in detail at the record of a proceeding when it decides whether an arguably erroneous decision depriving someone of a procedural right is so important that it justifies a holding that the petitioner has suffered a procedural injury. By contrast, a reviewing court can consider the entire record of a proceeding when it decides whether an erroneous deprivation of a procedural right was harmless. It follows logically that courts must be more willing to engage in broad generalizations when they apply the procedural injury doctrine than when they apply the harmless error rule.

Second, the consequences of a determination that a petitioner has or has not suffered a procedural injury caused by an agency action are different from the consequences of a determination that any such injury suffered by a petitioner was or was not harmless. A determination that a petitioner did not suffer a procedural injury ends a case with a holding that the petitioner lacks standing to obtain review of the agency action. In that situation, the court never has an opportunity to decide whether the procedural injury defeated "substantial justice" and affected "the substantial rights of the parties" by considering the nature and effects of the deprivation of the procedural right in the overall context of the full record. The highly contextual case specific harmless error rule would serve no purpose at all if 
courts were to apply a version of the procedural injury test that precludes a court from reviewing agency actions to determine whether omission of a required procedure constituted harmless error in light of the nature and likely effect of the omission.

By contrast, a determination that a petitioner has suffered a procedural injury gives the reviewing court the power to review the case and leaves the court with the discretion to decide that any violation of procedural rights was harmless. It also leaves the court with discretion to decide that, even if the deprivation of the procedural right was not harmless, the court should choose a remedy that keeps the costs of the decision within reasonable bounds given the severity of the deprivation of the procedural right. In short, application of a single easy to meet procedural injury test leaves courts with ample means of furthering the resourcesaving purpose of the harmless error rule.

This difference suggests that courts should be much more willing to engage in broad generalization in the context of procedural injury determinations than in the context of harmless error determinations. Moreover, it suggests that courts should apply a test for determining whether a petitioner suffered from a procedural injury that is easier to meet than the test the court applies to determine whether an erroneous deprivation of a procedural right constituted harmless error. With these considerations in mind, we can turn to the circuit court opinions that apply the two types of tests to determine whether a petitioner has suffered a procedural injury. 


\section{Circuit court opinions that apply a plausibility test}

Many circuit court opinions apply an easy to meet plausibility test in determining whether an alleged deprivation of a procedural right qualifies as a procedural injury sufficient to support a grant of standing. Those opinions have been issued in many contexts, including the right to a hearing in an adjudication, ${ }^{20}$ the right to an environmental impact statement (EIS) before an agency takes a major federal action that significantly affects the petitioner's environment, ${ }^{21}$ the right to have notice of and to comment on a proposed legislative rule, ${ }^{22}$ the right to be free from the potential effects of illegal ex parte communications in a formal hearing, ${ }^{23}$ the right to have an enforcement proceeding decided by a forum with a constitutionally acceptable composition, ${ }^{24}$ and the right to be free from the potential adverse effects of an advisory committee whose composition violates the Federal Advisory Committee Act (FACA). ${ }^{25}$ Courts have not applied a probability test in any of these contexts. If they did, the petitioner would be unable to satisfy

\footnotetext{
${ }^{20}$ The Supreme Court recognized with approval the universal use of a plausibility test in the context of deprivation of hearing rights in its opinion in Lujan, note 3 supra, at 572.

${ }^{21}$ The Court also approved of the practice in the context of environmental impact statements in Lujan, id. at 572.

${ }^{22}$ Courts routinely entertain arguments by petitioners that an agency denied the petitioner the right to notice and comment conferred by APA $\$ 553$ by erroneously claiming that the rule was exempt from the notice and comment procedure. I collect and describe scores of such cases in my treatise, Pierce supra. note 2, at $\S \S 6.3,6.4,6.5 \& 7.10$. I have not read a single such opinion in which a court has required a petitioner to show that provision of the right to notice and comment probably would have caused the agency to issue a rule more favorable to the petitioner.

${ }^{23}$ E.g. Electric Power Supply Ass'n v. FERC, 391 F.3d 1255, 1262 (D.C. Cir. 2004). See generally Pierce supra. note 2 , at $\S 8.4$.

${ }^{24}$ FEC v. NRA Political Victory Fund, 6 F.3d 821,824 (D.C. Cir. 1993). See generally Pierce supra. note 2 at $\S \S 2.4$ and 2.5 .

${ }^{25}$ Courts routinely address arguments that an agency violated FACA without requiring a petitioner to prove the impossible -- that compliance with FACA probably would have changed the outcome of the proceeding. E.g., Public Citizen v. Department of Justice, 491 U.S. 440 (1989). For discussion of many other FACA cases, see Pierce supra. note 2, at §5.19.
} 
the test in the vast majority of cases. It is virtually impossible to "prove" that provision of any procedural safeguard that an agency unlawfully refused to provide "probably" would change the outcome of the case.

Each of the contexts in which courts have applied the easy to meet plausibility test involved alleged deprivation of procedural rights that satisfy the criteria the Supreme Court has identified as critical in applying the harmless error rule. Each involved deprivation of a fundamental procedural right. Each of the procedural rights at issue was either the subject of a Supreme Court opinion in which the Court held the right to be required by the Constitution or the subject of a statute in which Congress required the agency to provide the procedure before it takes a specified class of actions. In each case, the agency's arguably unlawful deprivation of the procedural right might plausibly have affected the substantive outcome, but in each case it is impossible to determine the likelihood that it had that effect without first considering the merits of the case. In each of these contexts, a holding that the petitioner lacks standing because it has not suffered a procedural injury would render it impossible for a court to determine the likely effects of the deprivation in the context in which it took place.

Conversely, in each of these contexts, a court can further the resourceconserving purpose of the harmless error rule even if it holds that the petitioner has standing because it suffered a procedural injury. The court has two opportunities to avoid imposing undue costs on agencies after it holds that a petitioner has suffered a procedural injury - by concluding that the error was harmless or by choosing a relatively low cost remedy even if it concludes that the 
error was not harmless. Numerous cases illustrate both of these means of furthering the purposes of the harmless error rule.

Thus, for instance, even though courts always hold that a party has standing attributable to a procedural injury when it alleges that an agency unlawfully deprived it of a hearing that might plausibly have changed the outcome of the case, courts routinely hold that errors made in admitting or excluding evidence in such a hearing ${ }^{26}$ and inadequacies in the agency's explanation of its decision after a hearing ${ }^{27}$ were harmless. Similarly, while courts invariably hold that a party has standing attributable to a procedural injury when it alleges that it was unlawfully deprived of the notice and comment rulemaking procedure prescribed by APA section 553, courts routinely apply the harmless error rule both to agency failures to provide adequate notice of a study on which it relied $^{28}$ and to agency failures to discuss adequately comments submitted by parties. $^{29}$ Moreover, courts couple their universal practice of holding that deprivation of the right to a hearing that is free from the potential adverse effects of unlawful ex parte communications qualifies as a procedural injury with regular application of the harmless error rule to such communications. ${ }^{30}$

\footnotetext{
${ }^{26}$ Courts are even more reluctant to reverse agencies based on erroneous evidentiary rulings than to reverse judgments in civil cases based on erroneous evidentiary rulings. See Richard Pierce, Use of the Federal Rules of Evidence in Federal Agency Adjudications, 39 Admin. L. Rev. 1 (1987).

${ }^{27}$ E.g., Shkabari v. Gonzales, 427 F.3d 324, 328-29 (6 $6^{\text {th }}$ Cir. 2005); Tourus Records v. DEA, 259 F.3d 731, 739 (D.C. Cir. 2001). See generally Pierce supra. note 2 at $\S 8.5$.

${ }^{28}$ E.g., Chamber of Commerce v. SEC, 443 F.3d 890, 900-901, 904 (D.C. Cir. 2006). See generally Pierce supra. note 2 at $\$ 7.3$.

${ }^{29}$ E.g., USA Group Loan Services v. Riley, 82 F.3d 708, 713-14 (7 ${ }^{\text {th }}$ Cir. 1996). See generally Pierce supra. note 2 at $\$ 7.4$.

${ }^{30}$ E.g., Louisiana Ass'n of Independent Producers \& Royalty Owners v. FERC, 958 F.2d 1101, 1111-12

(D.C. Cir. 1992). See generally Pierce supra. note 2 at $\$ 8.4$.
} 
Even when a court does not hold a procedural error harmless, it often furthers the resource-conserving goal of the harmless error rule by declining to impose a costly remedy. Thus, for instance, while courts invariably hold that a petitioner has standing based on a procedural injury when it alleges that an agency deprived it of the APA right to notice and comment rulemaking, courts frequently remand a rule without vacation when they conclude that the agency is likely to be able to correct any procedural errors on remand. ${ }^{31}$ Similarly, the courts combine the universal practice of holding that a petitioner has suffered a procedural injury when it alleges that it was the subject of a decision made by an agency with an unconstitutional composition with a willingness to apply any holding on the merits prospectively only to avoid imposing undue costs on agencies. ${ }^{32}$ And courts frequently refuse to vacate agency actions when they determine that the agency used an unlawfully composed advisory committee in making such a decision even though they routinely hold that deprivation of the statutory right to a properly composed advisory committee qualifies as procedural injury for standing purposes. ${ }^{33}$

\section{Circuit court opinions that apply a probability test}

I have found only two opinions in which circuit courts have held that a petitioner lacked standing because it did not demonstrate that an agency's

\footnotetext{
${ }^{31}$ E.g., Heartland Regional Medical Center v. Sibelius, 566 F.3d 193, 197-98 (D.C. Cir. 2009); Allied Signal v. NRC, 988 F.2d 146 (D.C. Cir. 1993). See generally Pierce supra. note 2 at 7.13.

${ }^{32}$ E.g., Buckley v. Valeo, 424 U.S. 1, 142 (1976). See geerally Pierce supra. note 2 at $\$ 2.4$.

${ }^{33}$ E.g., California Forestry Ass'n v. Forest Service, 102 F.3d 609 (D.C. Cir. 1996). See generally Pierce supra. note 2 at $\$ 5.19$.
} 
deprivation of a procedural safeguard probably changed the outcome of a case. Those cases are important, however, since one was a 2005 opinion $^{34}$ in which a panel of the D.C. Circuit held that a 1996 en banc D.C. Circuit opinion ${ }^{35}$ requires the D.C. Circuit to apply the probability test in all cases in which a petitioner relies on an alleged procedural injury as the basis for standing. If the 2005 panel opinion is correct in its characterization of the effect of the 1996 en banc opinion, the probability test will apply to the high proportion of administrative law disputes that are decided by the D.C. Circuit. Since the probability test will almost always yield a holding that a petitioner lacks standing, the D.C. Circuit's method of applying the procedural injury test has the potential to eliminate de facto the procedural standing doctrine, with major repercussions for administrative law. Uniform application of the probability test to all cases in which a petitioner claims standing based on a procedural injury would create a legal environment in which agencies could ignore virtually all constitutional and statutory procedural rights with little fear that any court would or could require them to provide the procedures.

The 2005 panel opinion was issued in Center for Law and Education v. Department of Education. ${ }^{36}$ The No Child Left Behind Act required the Department of Education (DOE) to use a negotiated rulemaking process to issue a rule to govern DOE oversight of state implementation of the Act. ${ }^{37}$ The Act explicitly required DOE to convene a negotiated rulemaking committee that "will

\footnotetext{
${ }^{34}$ Center for Law \& Education v. Department of Education, 396 F. 3d 1152, 1159 (D.C. Cir. 2005).

${ }^{35}$ Florida Audubon Society v. Bentsen, 94 F.3d 658, 664 (D.C. Cir. en banc 1996).

${ }^{36} 396$ F.3d 1152.

${ }^{37}$ Id. at 1154 .
} 
provide an equitable balance between representatives of parents and students and representatives of educators and education officials." ${ }^{38}$ The plaintiffs, including a parent of a potentially affected student, objected to the composition of the committee. ${ }^{39}$ The plaintiffs alleged that the composition of the committee violated the statutory requirement of an equitably balanced committee because only one of the 24 members of the committee represented the interests of parents and students. ${ }^{40}$ DOE rejected that argument and used the committee in the process of issuing a rule that the plaintiffs found objectionable on various grounds. ${ }^{41}$ The plaintiffs sought review of the DOE rule in a district court. The district court held for DOE on several grounds. ${ }^{42}$ The plaintiffs appealed to the D.C. Circuit. A majority of the D.C. Circuit panel addressed only the standing issue. ${ }^{43}$ It held that the plaintiffs lacked standing because they had not satisfied the procedural injury test. $^{44}$

The panel majority relied on the following reasoning to support its holding:

[A] procedural-rights plaintiff must demonstrate standing by 'show[ing] not only that the defendant's acts omitted some procedural requirement, but also that it is substantially probable

\footnotetext{
${ }^{38}$ Id. at 1154 .

${ }^{39}$ Id. at $1155-56$.

${ }^{40}$ Id. at 1155 .

${ }^{41}$ Id. at 1155 .

${ }^{42}$ Id. at 1156.

${ }^{43}$ Id. at 1156 .

${ }^{44}$ Id. at 1162 . The third member of the panel wrote a concurring opinion in which he disagreed with the majority's reasoning and conclusion with respect to the procedural injury test and concurred on the basis of his belief that the petitioner had failed to demonstrate that she had a concrete interest that was at stake in the rulemaking. Id. at 1166-68.
} 
that the procedural breach will cause the essential injury to the plaintiff's own interest. In other words, while we relax the imminence and redressability requirements, the procedural-rights plaintiff must still satisfy the general requirements of the constitutional standards of particularized injury and causation. ${ }^{45}$

The panel majority concluded that the plaintiff lacked standing because she had not demonstrated that inclusion of more representatives of parents or students on the negotiating committee probably would have produced a rule more favorable to her interests as a parent.

This reasoning is flawed on many grounds. First, it is inconsistent with the routine judicial practice of applying a plausibility test to all other alleged deprivations of procedural rights that are rooted in statutes or in the constitution. Thus, for instance, courts regularly hold that a petitioner has standing to obtain review of an alleged violation of the FACA requirement that an advisory committee must be "fairly balanced in terms of the point of view represented." similar to the statutory requirement of an "equitably balanced" committee the deprivation of which the court found inadequate to support standing in Center for Law and Education. Like the "equitably balanced" requirement in the No Child Left Behind Act and virtually all other statutory procedural requirements, the "fairly balanced" committee requirement of FACA could never support standing if a court used a probability test to apply it.

\footnotetext{
${ }^{45}$ Id. at 1159.

${ }^{46}$ See e.g., California Forestry Ass'n v. Forest Service, 102 F.3d 609 (D.C. Cir. 1996). See generally Pierce supra. note 2 at $\$ 5.19$.
} 
Second, the distinction the court drew between causation and redressability defies logic. In most situations, causation and redressability are functionally indistinguishable. In the context of most agency actions a court can redress an injury only by vacating and remanding the agency action with instructions to the agency to correct the error that led to the judicial rejection of the agency action. Courts routinely hold that an injury caused by an agency can be redressed by a judicial decision that vacates and remands the agency action. Courts necessarily apply the same test to redressability disputes and to causation disputes. It makes no sense to say that a court should apply a more relaxed test to determine whether an injury is redressable than it applies to determine whether the challenged agency action caused the alleged injury. That reasoning would require a court to say that a judicial decision vacating and remanding an agency action can redress an injury that was not caused by the agency action at issue.

Third, if courts use a probability test to apply the causation requirement of the procedural injury test, they will not have the opportunity to apply the version of the harmless error rule the Supreme Court announced in Shinseki in most cases. Application of the probability test to all cases in which an agency allegedly deprived a petitioner of a constitutionally or statutorily prescribed procedure would yield a holding that a court lacks Article III jurisdiction to review most agency actions to determine the effect of the alleged deprivation of a procedural right. As a result, in most such cases, the court would not be able to engage in the "case specific application of judgment based upon examination of the record" that the Court mandated in Shinseki.

The Center for Law and Education majority claimed ${ }^{47}$ that its application of a probability test in all procedural injury cases was required by the en banc D.C. Circuit ${ }^{47} 396$ F.3d at 1159. 
opinion in Florida Audubon Society v. Bentsen. ${ }^{48}$ If the majority interpreted Florida Audubon Society accurately, the D.C. Circuit must apply the probability test even if it is wrong unless and until the en banc Circuit overrules Florida Audubon Society. There are reasons to be skeptical of the accuracy of the Center for Law and Education majority's interpretation of the Florida Audubon Society opinion, however. First, other D.C. Circuit panels have not interpreted the Florida Audubon Society opinion to adopt a probability test for determining whether omission of a required procedure caused a procedural injury. Since the D.C. Circuit issued its en banc opinion in Florida Audubon Society, it has applied the easy to meet plausibility test in many other cases. ${ }^{49}$

Second, the Center for Law and Education majority adopted a simplistic interpretation of the Florida Audubon Society opinion that does not reflect accurately the primary concerns that caused the en banc court to hold that Florida Audubon Society (FAS) lacked standing. In the critical passage of its opinion, the Center for Law and Education majority attributed the following reasoning to the Florida Audubon Society court:

[A] procedural-rights plaintiff must demonstrate standing by 'show[ing] not only that the defendant's acts omitted some procedural requirement, but also that it is substantially probable that the procedural breach will cause the essential injury to the plaintiff's own interest. In other words, while we relax the

\footnotetext{
${ }^{48} 94$ F.3d 658.

${ }^{49}$ E.g., Chamber of Commerce v. SEC, 443 F.3d 890, 896 (D.C. Cir. 2006); Chamber of Commerce v. SEC, 412 F.3d 133, 138 (D.C. Cir. 2005); Electric Power Supply Ass'n v. FERC, 391 F.3d 1255,1262 (D.C. Cir. 2004).
} 
imminence and redressability requirements, the procedural-rights plaintiff must still satisfy the general requirements of the constitutional standards of particularized injury and causation. ${ }^{50}$

The first sentence in that passage is a direct quote from Florida Audubon Society. ${ }^{51}$ The second sentence is a misleading paraphrase of the court's lengthy discussion of standing.

The en banc court discussed many issues in the twelve-page opinion in which it held that FAS lacked standing. FAS sought review of a Directive in which the Secretary of the Treasury clarified an existing rule in a way that expanded the scope of a tax credit for the use of a blend of gasoline and an additive derived from ethanol. FAS argued that the agency violated NEPA by refusing to prepare an EIS before it issued the Directive. According to FAS, the agency had to prepare the EIS because the Directive was a major federal action that affected the environment.

FAS argued that it had standing derivative of the standing of its members who viewed wildlife in areas near farm lands. FAS argued that the Directive injured its members who viewed wildlife in areas near farm land because the clarification in the Directive would encourage farmers to plant more corn, which in turn would cause more agriculture-related pollution, which in turn would have adverse effects on the wildlife that the FAS members liked to observe in the vicinity of farm lands. As I read the en banc opinion, the holding had little if anything to do with the procedural injury doctrine. The holding was based on the en banc court's skepticism with respect to the lengthy alleged

\footnotetext{
${ }^{50} \mathrm{Id}$. at 1159 .

${ }^{51}$ Id. at $664-65$.
} 
causal chain between the challenged agency action and the concrete injury alleged as the basis for the FAS claim of standing.

The opinion has many passages that support my interpretation. The court divided the standing inquiry into two parts:

As in all cases, standing in an EIS suit requires adequate proof of causation. The conceptual difficulty with this requirement, in this type of case, is that an adequate causal chain must contain at least two links: one connecting the omitted EIS to some substantive government decision that may have been wrongly decided because of the lack of an EIS and one connecting that substantive decision to the plaintiff's particularized injury. ${ }^{52}$

The court had no difficulty resolving the first part of the causal inquiry in favor of the petitioner. The court recognized that the petitioner had linked the failure to prepare an EIS adequately with the agency action the petitioner challenged. ${ }^{53}$ The court had no choice but to recognize the adequacy of the causal link between failure to prepare an EIS and an agency action, since the Supreme Court used the adequacy of that causal relationship to illustrate its point that "procedural rights are special" in its 1992 opinion in Defenders of Wildilife..$^{54}$

The court described the reasoning in the district court opinion it upheld in a manner that focused on the court's real concern:

\footnotetext{
${ }^{52}$ Id. at 668 .

${ }^{53}$ Id. at 666.

${ }^{54} 504$ U.S. at 572 n.7.
} 
[T]he district court dismissed as "speculative" appellants' argument that the tax credit, by increasing the market for ETBE, would stimulate production of the corn, sugar cane and sugar beets necessary to make the ethanol from which ETBE is derived, and that this increased crop production would, in turn, necessarily result in more agricultural cultivation, with its accompanying environmental dangers, in regions that border wildlife areas appellants (or their members) use and enjoy. The court declared that, even if it presumed that the tax credit would increase corn and sugar production, appellants had advanced no credible evidence that the increased production would necessarily harm or even occur near the wildlife areas in Michigan, Minnesota, and Florida that appellants visit. Because appellants had not established a geographic nexus between the harm they asserted that the tax credit will likely cause and lands that appellants-or their members-use, the court ruled that appellants had not suffered the particularized injury necessary for standing. ${ }^{55}$

The court then made explicit the basis for its holding:

Appellants in this case premise their claims of particularized injury and causation on a lengthy chain of conjecture. In brief, appellants contend that the tax credit will cause more ETBE production, which in turn will cause more ethanol production, which consequently will cause more production of the corn and sugar necessary for ethanol, which will then cause more agricultural pollution, which,

\footnotetext{
${ }^{55} 94$ F.3d at 662.
} 
as this pollution is likely to occur on farmland bordering wildlife areas appellants visit, is also likely to harm the areas visited by appellants. As we are reviewing a motion for summary judgment, we require specific facts, not "mere allegations," to substantiate each leap necessary for standing. Because appellants have not adequately demonstrated either an injury to their particularized interest or that defendant's actions created a "substantial probability" of this injury, we conclude that they lack standing to sue for preparation of an EIS. ${ }^{56}$

In other words, the holding that FAS lacked standing had nothing to do with the procedural injury doctrine - the required causal relationship between the failure to provide a required procedure and the challenged agency action. It was based instead on the court's conclusion that there was an inadequate causal link between the challenged agency action and the concrete injury the petitioner alleged.

The majority of the en banc court may or may not have been right with respect to its determination that the petitioner failed to establish an adequate causal link between the agency Directive that increased the scope of a tax credit and the concrete injury alleged reduced pleasure from viewing wildlife in areas near farm lands. I find the dissenting opinion of four judges more persuasive than the opinion of the six-judge majority on that issue. Even if you accept the majority's reasoning, however, as all D.C. Circuit panels must unless and until the en banc court overrules the opinion, the opinion does not hold that a court must apply a probability test in determining whether a petitioner has suffered a procedural injury sufficient to support standing.

${ }^{56}$ Id. at 666. 


\section{Conclusion}

My attempt to use the harmless error rule as a point of entry in attempting to understand the procedural injury doctrine has persuaded me that the many cases in which courts apply an easy to meet plausibility test to determine whether there is an adequate causal relationship between the omitted procedure and the challenged action are correct. Application of the plausibility test to determine whether a petitioner has standing to challenge an agency action where an agency allegedly deprived a petitioner of a required procedural safeguard allows a court to review the entire record of the case to decide: (1) whether the agency was required to provide the procedure; (2) if so, whether the agency deprived the petitioner of that procedure; (3) if so, whether any such deprivation of a procedural right was harmless; and, (4) even if the deprivation was not harmless, whether it was sufficiently serious to justify grant of the often costly remedy of vacation and remand of the challenged agency action.

Application of a probability test has the opposite results. Since it is usually impossible to demonstrate that provision of a required procedure such as a hearing, an EIS, or notice and comment probably would change the results in a case, application of a probability test would have many unfortunate results. It would devalue the procedures required by the constitution and by statutes by encouraging agencies to deny procedural safeguards in all close cases. It would deprive courts of the opportunity to decide most important cases in which agencies allegedly deprived a party of such a right. It would also render irrelevant the nuanced and fact-specific harmless error rule, since courts 
rarely if ever would be in a position to engage in the detailed review of the entire record required to determine whether an agency's deprivation of a procedural safeguard was harmless or instead defeated "substantial justice" and affected "the substantial rights of parties." ${ }^{, 57}$

\footnotetext{
${ }^{57}$ See Wright, Miller \& Kane, supra. note 14, at $\$ 2883$.
} 